\title{
Illustrations, Maps, Figure, and Tables
}

\section{Illustrations}

One of the oldest living survivors of Japanese American internment

A grocery store in Japantown in the 1920 s

Furuya Company picnic, $193^{\circ}$

Re-creation of the evacuation at the Day of Remembrance, 1978

Camp Harmony re-created at Puyallup Fairgrounds, 1978

Girls' Day celebration in the late 1930 s

Children on a train heading for camp, 1942 85

Moving into a camp barracks, 1942

Racially mixed school near Beacon Hill, Seattle, around 1972 129

Asian American movement, Seattle, 1971

The staff of Asian Family Affair visits Minidoka, 1974

Sansei's birthday party, 1971

\section{Maps}

1. Seattle, Washington, and environs

2. Relocation and detention camps, World War II 


\section{Figure}

1. Logo for Redress

\section{Tables}

1. Asian population trends in Seattle

2. Asian population trends in the United States

3. Survey on the effects of Executive Order 9066

$5^{\circ}$ 